Studies in African Linguistics

Volume 28, Number 2, Fall 1999

\title{
ASPECTS OF THE PHONOLOGY OF LABIAL-VELAR STOPS*
}

\author{
Michael Cahill \\ SIL
}

\begin{abstract}
Phonological patterns of labial-velar stops [kp, gb] are distinctively different from other consonants in their distribution and participation in phonological processes. A summary of cross-linguistic (> 80 languages) patterns of labial-velars includes phonemic inventories, co-occurrence patterns with vowels and consonants, and phonological processes that involve labial-velars. To explain these patterns, phonetic distinctives of labial-velars are presented, as well as the historical development of labial-velars. Feature Geometry and Articulatory Phonology are shown to account for some patterns. The conclusion drawn is that some patterns are best explained by diachronic factors, and there is no single current phonological theory that adequately accounts for all the other patterns.
\end{abstract}

\section{Introduction}

Among the tasks of phonology is accounting for patterns of inventories and distribution, of alternations, and of co-occurrences. In this paper, I suggest that accounting for such patterns of labial-velar stops and nasals is best done with reference to more than one theoretical framework. This is in the spirit of Zsiga [1997], who showed that two different assimilation patterns of Igbo vowels were best handled in two quite different approaches. Indeed, I show in this paper that some labial-velar patterns are traceable to historical processes and not to active synchronic phonology per se at all. I also show that Feature Geometry can help resolve the disparate views

\footnotetext{
* This paper is part of a larger project in progress, and I hope to considerably expand my database of languages in the near future. For any comments or contributions of data, contact the author at SIL, 7500 W. Camp Wisdom Rd., Dallas, TX 75237, USA. I have appreciated very much the contributions made by my SIL colleagues, both with unpublished data and also in steering me to references I would not have discovered easily. Thanks also to Beth Hume, Keith Johnson, Brian Joseph, and David Odden at Ohio State University for discussions on the phonetics, history, and phonology of labial-velars, to three anonymous SAL reviewers and the editor for very helpful direction and comments, and particularly to Bruce Connell for many fruitful and enlightening suggestions over the last few years. To them be the thanks, to me be the blame for any shortcomings.
} 
over whether labial-velars must be primarily labial (or velar), as presented in Chomsky and Halle [1968] or must be regarded as coequally both labial and velar, as argued by Ohala \& Lorentz [1977]. The paper is organized as follows. In Section 2 , I present several phonological patterns of labial-velars, including behavior that marks labial-velars as unitary sounds, phonemic inventories and allophones, cooccurrence restrictions with both consonants and vowels, nasal place assimilation, and other phenomena. In Section 3, I sketch some of the phonetic properties of labial-velars. In Section 4, I briefly discuss some historical properties of labial-velars: how they develop and how they disappear, showing that some of these are a direct result of the phonetic properties of labial-velars, and that historical developments can account for some phonological patterns. In Section 5, I examine how some formal theoretical models can account for some patterns of labial-velar phonology. We will see that the Feature Geometry and Articulatory Phonology models can account for certain aspects of labial-velar phonology, but fall short in others, and while Optimality Theory is flexible enough to be able to describe the patterns discussed here, it adds few insights to the other models. A list of languages and sources consulted for this project is appended.

Labial-velars (kp, gb, $\mathrm{nm}$ ) occur in approximately $6 \%$ of the 317 languages surveyed in the UPSID database [Maddieson 1984]. They occur extensively in West and Central Africa, in a few languages of Papua New Guinea, and marginally, in at least two Caribbean Creole languages (which have an African substratum). This project currently has at least some data from over 80 languages, the references for most of which are listed in an appendix, even though not all are discussed in this text. I use "KP" as a shorthand to refer to both [gb] and [kp], and label the relatively rarer languages of Papua New Guinea with "PNG" when mentioning them.

\section{The Phonological Patterns}

Besides the phonological patterns discussed below which relate directly to representational issues, I also note here the extreme rarity of labial-velars syllable- or wordfinally. Amele of PNG is the only language I am aware of which has a syllable-final, word-internal labial-velar [Roberts 1987]. Languages which have phonetic wordfinal labial-velars are almost non-existent, with only five languages I am aware of, and two of these are marginal cases. Adioukrou [Herault 1969, 1982] has labialvelars in final position, ${ }^{1}$ as do Momi (Vere) and Hyam (Jaba) (both Roger Blench, p.c,). Ndyuka, a Creole language of Suriname, has word-final [gb] in ideophones only [Huttar \& Huttar 1994], e.g., ppagb 'bang!', ffagbgb 'id. for swift action' (the $g b g b$ word-finally represents an extra-long closure). The other is [kp, $\mathrm{nm}]$ in Vietnamese, which are allophones of /k, $\mathrm{y} /$ [Liêm 1970:138, 141].

2.1. Labial-velars as units. Labial-velars are complex sounds with more than one component, but several behavioral patterns mark them as phonologically one unit.

1 Thanks to Rod Casali and an anonymous reviewer for pointing out these references, and to Ralph Hill [p.c.] for confirming the pattern. 
In Ewe gerund formation, the first consonant of a verb is reduplicated in a prefix to form the gerund [Ansre 1963]. If there is a consonant cluster word-initially, only the first member of that cluster is reduplicated, as in fle $\rightarrow$ fe-flee below. Significantly, when a labial-velar is the initial consonant in a verb, the entire labial-velar reduplicates as a unit in the gerund form, as seen in the last two forms below.

(1) Ewe reduplication

$\begin{array}{lll}\text { fo 'to beat' } & \text { fo-fo } & \text { 'beating' } \\ \text { bia 'to ask' } & \text { ba-biam } & \text { 'asking' } \\ \text { fle 'to buy' } & \text { fe-flee } & \text { 'bought' } \\ \text { kplo 'to lead' } & \text { kpo-kplo } & \text { 'leading' } \\ \text { gbla 'to exert oneself' } & \text { gba-gblam } & \text { 'exerting oneself' }\end{array}$

Mano and Kaanse are languages with no phonemic $/ \mathrm{nm} /$. However, phonetic [nm] occurs as an allophone of /gb/ before nasal vowels [Welmers 1973:47, Showalter p.c.]. The labial-velar nasalizes as a unit and not partially (but see Béarth \& Zemp [1967] for partial nasalization of a labial-velar). Also in Kaanse, /kp/ is realized as [gb] in a voiced context, after a nasal [Showalter 1997].

(2) Kaanse

sànı kpógorò 'sheep-shelter'

sû́n gbógorò 'chicken-shelter

2.2 Inventories. Inventories of labial-velar stop phonemes and related sounds are given in (3), while allophones of $/ \mathrm{kp} /$ and $/ \mathrm{gb} /$ are given in (4).

There are several interesting patterns to note from the tables in (3) and (4). First, phonetic $\left[\mathrm{KPw}^{\mathrm{w}}\right]$ is not rare, but phonemic $/ \mathrm{KPw} /$ is at best quite rare, and may be non-existent. ${ }^{2}$ In Deg and several other languages, all stops except labial-velars have labialized versions as phonemes: /p, $\mathrm{p}^{\mathrm{w}} /, / \mathrm{b}, \mathrm{b} \mathrm{w} /, / \mathrm{t}, \mathrm{tw} /, / \mathrm{d}, \mathrm{d}^{\mathrm{w}} /, / \mathrm{k}, \mathrm{k}^{\mathrm{w}} /, / \mathrm{g}, \mathrm{g}^{\mathrm{w}} /$, but $/ \mathrm{kp}$, $\mathrm{gb} /$, and $n o t / \mathrm{kp}^{\mathrm{w}}, \mathrm{gb}^{\mathrm{w}} /$. Second, several languages, over a dozen, have /gb/ but no $/ \mathrm{kp} /$, though cross-linguistically a voiced stop usually implies the presence of a voiceless one (for discussion of the phonetic basis for the bias against voiced obstruents, see Ohala [1997]). The languages in my database thus far (Efik, Ibibio, Nkonya, and Lama) which have $/ \mathrm{kp} /$ but no $/ \mathrm{gb} /$ all also have related asymmetries in

2 KPw has been reported in Nupe. Smith [1967] mentions /kpwà/ [kpwò] 'to be cheap,' but elsewhere in the same article says labial-velars have "an allophone [my emphasis] with a labio-velar onglide to a following back vowel" (p. 154). Thus Nupe may well group with those languages which have $[\mathrm{KPw}]$ as an allophone of $/ \mathrm{KP} /$ before round vowels. Another distinct possibility is that there is a stop-glide sequence in Nupe. The distribution of the independent glides lends support to this. /w/ almost always occurs before /a, o, u/, and /y/ before /a, e, i/, quite similar to the distribution of the "labialized" and "palatalized" stops [Banfield 1914]. Because of this, Nupe cannot be regarded as a firm counter-example. Welmers [1973:62] mentions Nupe as the only case known to him with / kpw, gbw/, but he also notes the peculiarities above. Tarok [Roger Blench, p.c.] has also been reported to have a contrast between $/ \mathrm{gb} / \mathrm{and} / \mathrm{gb}^{\mathrm{w}} /$, but I have not had the opportunity to investigate this in detail. 
(3) Phonemic Consonants

\begin{tabular}{|c|c|c|c|c|c|c|c|c|c|c|c|}
\hline & $\mathrm{kp}$ & $\mathrm{gb}$ & $\mathrm{k}^{\mathrm{w}}$ & $\mathrm{g}^{\mathrm{w}}$ & $\mathrm{kp}^{\mathrm{w}}$ & $\mathrm{gb}^{\mathrm{w}}$ & $\mathrm{kp}^{\mathrm{y}}$ & $g b^{y}$ & $\mathrm{p}^{\mathrm{w}}$ & $b^{w}$ & 6 \\
\hline many languages & $\mathrm{x}$ & $\mathrm{x}$ & & & & & & & & & \\
\hline $\begin{array}{l}\text { Deg, Kpelle, Moru, } \\
\text { Nchimburu, Ijo (Kal) }\end{array}$ & $\mathrm{x}$ & $\mathrm{x}$ & $\mathrm{x}$ & $\mathrm{x}$ & & & & & $\mathrm{x}$ & $\mathrm{x}$ & \\
\hline $\begin{array}{l}\text { Ngiti, Mündü, Mödö, } \\
\text { Lendu, } 6 \text { from UPSID }\end{array}$ & $\mathrm{x}$ & $\mathrm{x}$ & & & & & & & & & $\mathrm{x}$ \\
\hline Dan & $\mathrm{x}$ & $\mathrm{x}$ & $\mathrm{x}$ & $\mathrm{x}$ & & & $\mathrm{x}$ & $\mathrm{x}$ & $\mathrm{x}$ & $\mathrm{x}$ & $\mathrm{x}$ \\
\hline Chakosi, Mada & $\mathrm{x}$ & $\mathrm{x}$ & $\mathrm{x}$ & $\mathrm{x}$ & & & $\mathrm{x}$ & $\mathrm{x}$ & & & \\
\hline $\begin{array}{l}\text { PNG, Krahn, Temne, } \\
\text { Tepo, North. Senufo } \\
\text { languages, Maninka, } \\
\text { Bambara }\end{array}$ & & $\mathrm{x}$ & & & & & & & & & \\
\hline Efik*, Nkonya*, Lama* & $\mathrm{X}$ & & & & & & & & & & \\
\hline
\end{tabular}

* these do not have /g/ either.

(4) Allophones of $/ \mathrm{kp}, \mathrm{gb} /$

\begin{tabular}{|l|c|c|c|c|c|c|c|c|c|c|}
\hline & $\mathrm{kp}$ & $\mathrm{gb}$ & $\mathrm{k}^{\mathrm{w}}$ & $\mathrm{g}^{\mathrm{w}}$ & $\mathrm{kp}^{\mathrm{w}}$ & $\mathrm{gb}^{\mathrm{w}}$ & $\mathrm{kp}^{\mathrm{y}}$ & $\mathrm{gb}^{\mathrm{y}}$ & $\mathrm{tp}$ & $\mathrm{db}$ \\
\hline many & $\mathrm{x}$ & $\mathrm{x}$ & & & & & & & & \\
\hline Dagaari, Kusaal & $\mathrm{x}$ & $\mathrm{x}$ & & & $\mathrm{x}$ & $\mathrm{x}$ & & & & \\
\hline Dagbani, Nzema & $\mathrm{x}$ & $\mathrm{x}$ & & & & & & & $\mathrm{x}$ & $\mathrm{x}$ \\
\hline Hanga & $\mathrm{x}$ & $\mathrm{x}$ & & & & & $\mathrm{x}$ & $\mathrm{x}$ & & \\
\hline Gwari, Nafaara & $\mathrm{x}$ & $\mathrm{x}$ & & & & $\mathrm{x}$ & & & & \\
\hline Tampulma & $\mathrm{x}$ & $\mathrm{x}$ & & & & & & $\mathrm{x}$ & & \\
\hline
\end{tabular}

their consonantal systems. Efik, Ibibio and Nkonya not only lack /gb/, but also lack /g/. Lama has no voicing contrasts at all in its consonants. Third, Nzema has [tp, db] as allo-phones of $/ \mathrm{kp}, \mathrm{gb} /$ before front vowels [Westermann \& Bryan 1952:90]. Similarly, Dagbani [Wilson \& Bendor-Samuel 1969] has [tp, db] as allophones of $/ \mathrm{kp}, \mathrm{gb} /$ before [i] (Knut Olawsky has informed me that these sounds are phonetically more palatal than alveolar). 
2.3 Co-occurrence restrictions. While in many languages, there are no co-occurrence restrictions with labial-velars, such restrictions do exist in other languages. Frafra, Buli, Gwari, Dagbani, Mayogo, Moba, Santa Ana (PNG), Digo, and others such as the western Sawabantu languages, have few or no back round vowels following $/ \mathrm{KP} /$ (see Appendix for references to these languages). Cross-linguistically, if there is a class of vowels missing after KP, it is the high back round vowels / $\mathrm{U} /$, and sometimes the mid back round vowels $/ \mathrm{O} /$. In the languages in my database to date, $/ \mathrm{U} /$ and $/ \mathrm{O} /$ do occur after /b, p/, so this restriction does not apply to labial stops in general. 3

However, in other restrictions, labial-velars do group together with labial consonants. Significantly, Ngbaka and Kukú have no labial consonants in the same word as other labial consonants, including labial-velars [Thomas 1963, Selkirk 1993, Cohen 1997]. Similarly, Kaanse has no labial consonants in the same morpheme as other labials, including labial-velars [Showalter 1997]. Also, in Nupe, /ã/ has an allo-

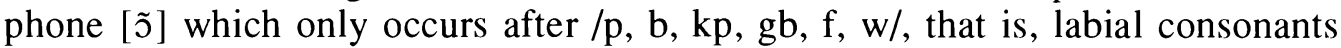
[Smith 1967].

2.4. Nasal Place Assimilation. In this section, we see that a nasal has been reported as assimilating in place to a following labial-velar stop as either [ $\mathrm{nKP}]$ or $[\eta \mathrm{mK}]$ in various languages (and both in Konni). Since these are acoustically quite similar to each other, it is legitimate to query the reliability of the transcriptions. Actually, there are two reasons why relying on published accounts of nasals before KP involves some degree of indeterminacy. One is that in some sources, there has been an orthographic convention established which is not identical with the phonetic reality. For example, Yoruba uses orthographic $\{\mathrm{p}\}$ to represent $/ \mathrm{kp} /[$ Folarin 1987, inter alia] and orthographic $\{\mathrm{m}\}$ for [nm]. Welmers [1973] also notes that orthographically for African languages, he prefers to write $\{\eta\}$ rather than $\{m\}$ for the labial-velar nasal [nm].

The second reason is that, especially for the unpracticed non-native speaker, the different nasals possible before a labial-velar stop are not always easy to distinguish. The auditory difference between [ $\mathrm{nmkp}]$ and [ $\mathrm{\eta kp}]$ is not great, particularly when not preceded by a vowel. The reason for this is easy to see; [ $\mathrm{jm}]$ has two places of articulation: a front $[\mathrm{m}]$ and a rear [n]. In the resonating cavity composed of the oral and nasal tracts, $[\mathrm{nm}]$ creates a complete constriction at the same location as that produced when [ $\mathrm{\eta}]$ is pronounced. It is this rearmost constriction that defines the length of the oral part of the resonating cavity. As Ohala \& Ohala [1993:236] note, "Any additional constriction forward of that point is acoustically irrelevant." But to distinguish [nmkp] and [nkp] reliably, it is important to use one's eyes as well as ears. That having been noted, it is possible to reliably distinguish the two when one knows what to look and listen for. The pattern that emerges from the literature across languages is that there are indeed two distinct types of nasal assimilation before labial-velars.

3 An anonymous reviewer points out that there are NW Bantu languages which lack a $U$ after both labial-velars and labials. I have not seen the data for these as yet, but this appears to be a pattern where labial-velars and labials pattern together, as discussed below. 
2.4.1 Assimilation as [ym] preceding labial-velars. Sagey [1990] cites several languages in which a nasal assimilates to KP as [ $\mathrm{nm}]$, either as a full segment or as the nasal component of a pre-nasalized stop, as in (5).

(5) a. Nasal preceding labial-velars

$\begin{array}{lll}\text { Kpelle } & \boldsymbol{\eta} \mathbf{m}-\text { gbin } & \text { 'myself' } \\ \text { Yoruba } & \text { o } \boldsymbol{\eta m} \text { gbo } & \text { 'he is hearing' } \\ \text { Dan } & \boldsymbol{\eta} \boldsymbol{m} \text { gbe } & \text { 'my arm' }\end{array}$

b. Prenasalized labial-velars

$\begin{array}{lll}\text { Sango } & \boldsymbol{g}_{\text {g }} \text { ba } & \text { 'to remain' } \\ \text { Tiv } & a^{\boldsymbol{\eta}^{\boldsymbol{m}} \text { gbahom }} & \text { 'he approached' } \\ \text { Gwandara } & \text { gbo }{ }^{\boldsymbol{\eta} \boldsymbol{m}} \text { gboro } & \text { 'steep river bank' }\end{array}$

2.4.2 Assimilation as [ $\boldsymbol{\eta}$ ] before KP. Sagey does not mention other types of nasal place assimilation, but they are actually quite common. Ryder [1987] cites several languages in which a nasal assimilates to KP as [n]. Besides these and the ones cited below, Anufo (Chakosi), Birifor, Chumburung, Dagbani, Deg, Gã, Gwari, Konkomba, Kusaal, and Vagla (cited in the references) also display this pattern.

(6) a. Nasal preceding labial-velars: Dagaari [Kennedy 1966, personal data) kpànkpàn 'upper arm' gbángbán 'noon' и́ kpánò 'I lock' ̀̀ kpiérà 'I am entering'

b. Prenasalized labial-velars: Bongo prenasalized stop [Kilpatrick 1985]

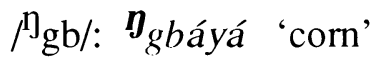

2.4.3 Konni: both types of assimilation. Konni, a Gur language of northern Ghana, exhibits both the above patterns of nasal place assimilation [Cahill 1992, 1998]. Within words, a nasal assimilates in place as [ $\mathrm{\eta}$ ] before KP. However, across words, a nasal assimilates as [nm].

(7) Nasal assimilation type 1: [n] before a labial-velar within words:

a. Single-morpheme words:

$$
\begin{array}{ll}
\text { tìngbán } & \text { 'floor' } \\
\text { bìnkpìán } & \text { 'shoulder' }
\end{array}
$$

b. Compound nouns 4

tàn-kpí'án 'bush-partridge [lit. dirt-chicken]' (cf. tàn-tí 'dirt')

kàày-kpín 'cheekbone [lit. cheek-sheanut]' (cf. kààmín 'cheek')

\footnotetext{
4 In Konni, compound nouns can be distinguished from associative noun phrases by the presence of a suffix on the left noun of an associative construction and a High associative tone on the second noun in the associative construction.
} 
c. Noun-adjective

dùùn-kpÍ'ing 'big horse [= horse-big]' (cf. dùùn-é 'horses')

bín-kpílán 'dry seed [= seed-dry]' (cf. bín-ní 'the seed')

(8) Nasal assimilation type 2: [nm] before a labial-velar across words

a. Pronoun 5

$\begin{array}{llll}\text { ỳm gbién } & \text { 'my pot' } & \text { ỳm kpàllí } & \text { 'my calabash' } \\ \text { j̀m gbálígí-yà 'I'm tired' } & \text { ìm kpátí-yà 'I've finished' }\end{array}$

b. Noun Phrases

sìnkpáánm kpáán 'peanut oil’ (cf. sìnkpáán)

c. Verb Phrases

kénm kpátì 'come finish'

kénm gbírígì 'come kneel'

2.4.4 Assimilation of nasals following labial-velars. Nasals preceding consonants are much more common than nasals following them, but the latter do occur in a number of languages. One of these is Senufo, Tyebaara dialect [Mills 1984]. A nasal following a labial-velar here assimilates as [m]. Mada [Price 1989] has an unusual syllable type: a stop followed by syllabic nasal. In these cases, the nasal assimilates to a preceding labial-velar as [nm].

(9) a. Senufo, Tyebaara dialect

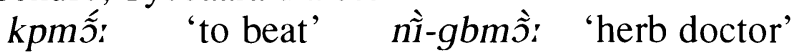

b. Mada

/kpm/ [kpyǹ] 'kapok tree'

/gbm/ [gbnm̀] 'canoe'

/kpakmki/ [kpa.kn.ki] 'tree stump'

2.4.5 Gwari. Gwari is interesting in that it may have a nasal either preceding or following a labial-velar. As analyzed by Rosendall 1992, Gwari has two nasal phonemes, $/ \mathrm{n} /$ and $/ \mathrm{m} /$. Of these two, $/ \mathrm{m} /$ does not assimilate to a following consonant, but $/ \mathrm{n} /$ does.

(10) No assimilation of $/ \mathrm{m} /$

àmwí 'dog' pìsémgbà 'cock'

5 The status of subject and possessive pronouns as words may be marginal in Konni, as they do not occur as independent utterances; they may be better viewed as clitics. Nonetheless, syntactically they act as independent words, and for phonological patterns such as this assimilation they group with independent words. 
(11) Assimilation of $/ \mathrm{n} /$ before consonants
a. sintóló
'leaf'
mìnt ${ }^{1}$
'saliva'
mínsà
'man'
$\begin{array}{ll}\text { b. jèmpjé } & \text { 'feces', } \\ \text { kàmbá } & \text { 'maize' }\end{array}$
tfínkpè 'stool'
w'édzíngbmà 'dark'
c. ’̀wá 'to need'

A nasal assimilates to a preceding stop only if the stop is labial. As seen in other languages, labial-velars are included in the class of labials here.

(12) a. No assimilation

$\begin{array}{ll}\text { tnútnúnù } & \text { 'rubbish' } \\ \text { dnásò } & \text { 'river' } \\ \text { kná } & \text { 'send' } \\ \text { ágnáná } & \text { 'jump' }\end{array}$

b. Assimilation

$\begin{array}{ll}\text { bmà } & \text { 'break' } \\ \text { gbmínà } & \text { 'feather' } \\ \text { igbm'á } & \text { 'fish' } \\ \text { kpmàmí } & \text { 'okra' } \\ \text { b }^{w a ́ k p m i ̀ ~} & \text { 'left side' }\end{array}$

From the languages examined in this section, it is evident that nasal place assimilation seems never to yield [mKP] or [KPy] (recall that the nasal [mgb] in (10) is analyzed as non-assimilation). A complete nasal assimilation [ $\mathrm{nm}]$ is attested either preceding or following a labial-velar, but if there is partial place assimilation, it yields $[\eta \mathrm{KP}]$ or $[\mathrm{KPm}]$.

\subsection{Other labial-velar phonology}

2.5.1 Blocking of round harmony: Nawuri. In the Nawuri prefix /gI-/, the vowel is round if the stem vowel is round [Casali 1995]. But if the initial stem consonant is labial (including labial-velars), the process is blocked. In this process, labial-velars group together with labials as a natural class, but not with velars.

(13) a. before [-round] stem vowel

[gi-ni] 'tooth' [gi-ke:li] 'kapok tree'

b. before [+round] stem vowel - round spread:

[gu-jo] 'yam' [gu-ku:] 'digging'

c. before [+round] stem vowel and labial stem consonant blocking of spread:

[gi-pula] 'burial' [gi-kpo:] (type of dance) 
2.5.2 Neutralization of KP - the case of Amele. In Amele (PNG), /gb/ is neutralized with /b/ word-finally [Roberts 1987]. The morpheme \{we\} word-medially, is $[\mathrm{gb}]$, but $[\mathrm{p}]$ word-finally.

$$
\begin{array}{ll}
{[\text { 'ho-gb-ə] }} & \text { 'we came (today)' } \\
{[\text { ho-'lo-p] }} & \text { 'we used to come.' } \\
/ \mathrm{fe}+\mathrm{fe}+\mathbf{g b} / \rightarrow[\text { fefep] } & \text { 'as we see (SS)...' }
\end{array}
$$

Efik has been cited as a similar case [Welmers 1973], since [kp] appears only in syllable-initial position, but [p] appears only in syllable-final position. However, there are no alternations as in the Amele case, and [b] and [p] also have the same type of complementary distribution, so Cook $[1969,1985]$ treats [p] as an allophone of /b/ rather than of $/ \mathrm{kp} /$. In the light of Cahill [to appear], it is perhaps better to treat Efik $/ \mathrm{kp} /$ as merely having a restricted distribution, as in many other languages.

2.5.3 Vowel assimilation in Amele. In Amele (PNG), /e/ surfaces as [o] before back round vowels, across an optional consonant (see (a) below). The same happens immediately preceding /w/ or /gb/ (see (b)), but not when the /gb/ is word final and realized as $[\mathrm{p}](\mathrm{see}(15 \mathrm{c}))$.

(15) Amele /e/ $\rightarrow$ [o]: [Roberts 1987: 363-5]
a. $/ \mathrm{fe}+\mathrm{u}+\mathrm{m} / \rightarrow$ [foum] 'I would have seen'
/fe+?e+hul/ $\rightarrow$ [fe?ohul] 'we(2) see(DS)...'
$/ \mathrm{fe}+\mathrm{fe}+\mathrm{hul} / \rightarrow$ [fofohul] 'as we (2) see (DS)...'
b. $/ \mathrm{fe}+\mathrm{w}+\mathrm{a} / \rightarrow$ [fowa] 'we (2) saw (today past)'
$/ \mathrm{fe}+\mathrm{gb}+\mathrm{a} / \rightarrow$ [fogba] 'we saw (today past)'
c. $/ \mathrm{fe}+\mathrm{fe}+\mathrm{gb} / \rightarrow[\mathrm{fefep}] \quad$ as we see (SS)...'

Note that $\underline{\mathrm{e}}$ rounds before segments which have both [dorsal] and [labial] features, that is $[u, o, w, g b]$. Neither feature by itself is sufficient to cause the rounding; $\underline{\mathrm{e}}$ does not round before $[\mathrm{k}]$ or $[\mathrm{p}]$.

2.6. Summary of above - What needs explanation. To summarize the above, an adequate explanation needs to be proposed for the following phenomena discussed above:

1. Distinguish the phonemes /KP, $\mathrm{K}^{\mathrm{w}} /$

2. Distinguish the allophones [KP], [KP $]$, [KPy $]$, [TP]

3. Account for the rarity or lack of $/ \mathrm{KP}^{\mathrm{w}} /$, but the not uncommon presence of $\left[\mathrm{KP}^{\mathrm{w}}\right]$

4. Account for the not-uncommon occurrence of $/ \mathrm{gb} /$ without $/ \mathrm{kp} /$ 
5. Account for single-C behavior vs. edge-effects

a. reduplication, voicing as single $\mathrm{C}$

b. nasals $\rightarrow \eta$ before KP and $\mathrm{m}$ after KP

6. Account for vowel restrictions after KP

7. Account for Nawuri blocking of round harmony.

8. Account for Amele neutralization of KP word-finally

9. Account for Ngbaka, Kukú, and Kaanse consonant co-occurrence restrictions

10. Account for the grouping of $\underline{\mathrm{KP}}$ with $\underline{\mathrm{u}, \mathrm{O}, \mathrm{w}}$ in Amele /e/ $\rightarrow[\mathrm{o}]$

\section{Some phonetics of labial-velars}

In this section a selection of phonetic characteristics relevant to the previous phonological patterns is presented. For more complete details on phonetic characteristics of labial-velars, see Connell [1994] and Ladefoged \& Maddieson [1996].

3.1 Articulatory mechanisms. Ladefoged [1968] notes three mechanisms for producing labial-velars:

1. Simple pulmonic airstream. (2 languages)

2. Pulmonic egressive and velaric ingressive airstream. Dorsum slides back, air flows into oral cavity from both directions. (23 languages)

3. Pulmonic egressive, velaric ingressive, glottalic ingressive airstreams. Partly voiced. (8 languages)

Note that most languages have an ingressive mechanism (some investigators label it "suction"). In light of Connell's [1994] discussion of intra-speaker variation, it is possible that these three categories may be reduced to two: one with pulmonic egressive airstream and one with some variety of ingressive airstream (but see discussion in Ladefoged \& Maddieson [1996: 342-343]).

Two other details of the phonetics of labial-velars are relevant to their phonological patterns. First, some, such as Ibibio, Kana, and Obolo, have partial voicing even of "unvoiced" /kp/ [Connell 1994], as Ladefoged also noted. Second, labialvelars are typically unaspirated, even when other stops are aspirated. For example, in Nupe, all voiceless stops except $/ \mathrm{kp} /$ are aspirated [Smith 1967]. In Phwin, a Gur language of Burkina Faso, aspiration is contrastive on all voiceless stops except $/ \mathrm{kp} /$ [Kevin Warfel, p.c.]. These examples could be multiplied. In writings on several other languages (twelve to date), $/ \mathrm{kp} /$ is singled out from among voiceless stops as unaspirated. Only three phonological sketches I have seen mention $/ \mathrm{kp} /$ as aspirated along with the other voiceless stops. These are for Hanga [Hunt 1981], Nchimburu [Price 1975], and Dagaare [Kennedy 1966]. However, upon reexamination, none of these is correct. Adams Bodomo [p.c.] informs me that [kp] in Dagaare is less aspirated than [p], Keith Snider [p.c.] informs me that [kp] in Nchimburu is actually unaspirated, and Geoffrey Hunt [p.c.] informs me that upon examining the recordings with acoustic analysis software, $[\mathrm{kp}]$ in Hanga is unaspirated, unlike other 
voiceless stops. (It should be noted that none of the three original writers had access to tools for acoustic analysis.) Of course, many phonologies do not even mention aspiration at all, on any stops. Such is the case in Cahill [1992] for Konni, but Cahill [1999] shows in waveforms the lack of aspiration in [kp] compared to [p], $[\mathrm{t}]$, and $[\mathrm{k}]$.

3.2 Articulatory overlap. Labial-velars are generally transcribed as [kp, gb], not [pk, bg], and this is no accident. 6 Perceptually and articulatorily, the velar onset precedes the labial one, and the labial release follows the velar release. This is supported by spectrograms from Dedua (PNG), Efik, Ibibio, and others [Connell 1994, Ladefoged \& Maddieson 1996 and references therein].

(16) Electromagnetic articulography shows overlap of the gestures [Ladefoged \& Maddieson 1996].

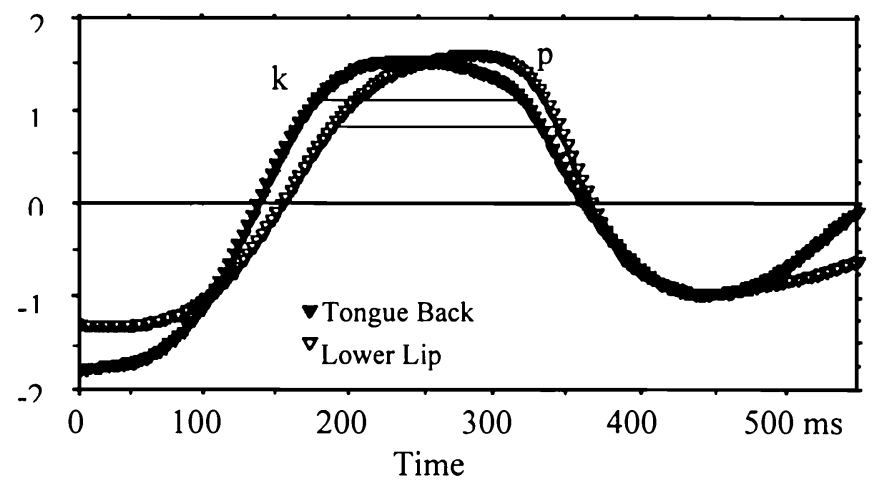

Coordination of lower lip and tongue back movements in the Ewe word akpa. Y-axis is vertical displacement; horizontal lines indicate the likely duration of actual contact of the articulator.

Maddieson has also performed direct measurement of movement of the articulators with electromagnetic articulography, with electromagnetic sensing of the position of metal pellets glued to the articulators. The data shown below support the spectrographic evidence that the velar gesture precedes the labial one.

\section{Historical}

4.1 Where labial-velars come from. Several diachronic studies include labial-velars as part of larger studies; see Ponelis [1974] and Connell [1994] for more in-depth discussion of the historical development of labial-velars. To illustrate some common

6 Occasionally in some older literature one finds a transcription as [pk, bg], in a context which suggests the author was not concentrating on the order of the articulations. Also, Shona has been transcribed as having [pk], but Maddieson (1990) shows that these are separate and not overlapping articulations. 
patterns, I cite here another study which concentrates on labial-velars. In the Sawabantu group of languages in western Cameroon, Mutaka and Ebobissé [1996/97] show that a historical prefix $* k u$ - was realized as $* k w$ - before vowels, and that $*$ kw $>\mathrm{kp}$ in the Western Sawabantu group (below), as well as $* \eta_{\mathrm{gw}}>\eta_{\mathrm{gb}}, * 6 \mathrm{w}>\mathrm{gb}$ and $*_{\mathrm{mw}}>\mathrm{nm}$.

(17) Sawabantu words with historical prefix *ku

\section{Eastern Sawabantu}

a. 'diarrhea' kúbwako

'skin'

b. 'partridge'

'sword'

'death' kobo

kwalé, kwadé

kwátá

kwédí
Western Sawabantu

kúgbako

kowo

kpaé

kpátá

kpélí

This historical development hypothesis is supported by the fact that synchronically, some languages produce $K P$ from $K w$. In Noni [Hyman 1981], /K+w/ often is manifested as [kp, gb] (also see Kelly [1988] for Digo).

(18) Noni nouns singular marker $/ \mathrm{w} /$

$\begin{array}{lll}\text { singular } & \text { plural } & \text { gloss } \\ \text { twén } & \text { tén } & \text { 'vine branch' } \\ \text { kwen } \sim \text { kpen } & \text { ken } & \text { 'firewood' } \\ \text { gwéé } \sim \text { gbéé } & \text { géé } & \text { 'hundred' }\end{array}$

However, in Aghem [Hyman 1979], present-day /kp, gb/ came from historical *pw, *bw (see Demolin [1995], Connell [1994] for other *Pw). The immediate predecessors of labial-velars seem always to be labialized consonants, whether $* \mathrm{Pw}$ or $* \mathrm{Kw} .7$

(19) Aghem nouns plural marker /w/

\begin{tabular}{|c|c|c|}
\hline singular & plural & gloss \\
\hline ḱ́-nân & ó-nwân & 'cocoyam' \\
\hline$k \grave{t}-t \check{\varepsilon} \varepsilon$ & ò-tw̌̌ $\varepsilon$ & 'cricket' \\
\hline kí-bá? & ó-gbá? & 'rope' \\
\hline$k^{\prime}-b \varepsilon^{\prime}$ & ó-gbé & 'fufu' \\
\hline
\end{tabular}

4.2 Where labial-velars go. The labial-velar stops in northern Senufo languages (Gur family) merged $*^{*} \mathrm{kp}$ and $*_{\mathrm{gb}}$ into gb. Sucite is one example of this. It has no $/ \mathrm{kp} /$, but $/ \mathrm{gb} /$ is quite common, despite the relative uncommonness of other voiced

7 Kelly [1974] notes that $\mathbf{C f}$ and $\mathbf{C v}$ arose from a proto-Cu in Fan. A [kf] is a possible candidate for an intermediate between $\left[\mathrm{k}^{\mathrm{w}}\right]$ and $[\mathrm{kp}]$ in at least some cases. 
stops relative to voiceless ones [Garber 1987]. Supyire took the next step and merged gb with $\mathrm{b}$, and today has no labial-velar stops, unlike most other Senufo languages [Carlson 1994:8-9]. As a result of these mergers, the Supyire / $b$ / is disproportionately common, the results of combining the frequencies of words with $*$ b, $* \mathrm{gb}$, and ${ }^{*} \mathrm{kp}$.

The labial-velars in Papuan languages seem to have followed the same patterns as the African ones. For example, Ono (PNG) presently has only /gb/ as a labial-velar, unlike other stops which have voiced/voiceless pairs [Phinnemore 1985]. However Wacke [1931] reported a contrast between $/ \mathrm{kp} /$ and $/ \mathrm{gb} /$, as well as the nasal $/ \mathrm{nm} /$. Wacke's $3 / \mathrm{gm} /$ words are all pronounced with $/ \mathrm{m} /$ today. Assuming the accuracy of Wacke's report, $\mathrm{kp}$ merged with $\mathrm{gb}$, and $\mathrm{nm}$ merged with $\mathrm{m}$. The Santa Ana language of Makira Province, Solomon Islands, also has only /gb/ [Greg Mellow, p.c.].

Dolphyne \& Kropp Dakubu [1988] note in their article on Volta-Comoé that "Nzema-Anyi-Baule and Chakosi have /kp/ where Akan has /p/", another case in which a labial-velar changed to a labial. For more on the historical development of labial-velars, see Demolin [1995] and Connell [1991, 1994, 1995].

In sum, historically, it seems common (though not universal) that:
(20) a) $\mathrm{KU}>\mathrm{KW}$
(where $\mathrm{U}=\mathrm{u}, \mathrm{u}$ )
b) $\mathrm{KW}>\mathrm{KP}$, then
c) $\mathrm{kp}>\mathrm{gb}$ and/or
d) $\mathrm{KP}>\mathrm{P}$

These historical developments help account for some of the distributional patterns of labial-velars. Sound change (20a) above accounts for the vowel restrictions found after KP noted in Sec. 2.3. A perceptibly labialized $\mathrm{K}$ would not develop before a round vowel (i. e., ${ }^{*}$ kua $>\mathrm{k}^{\mathrm{w}}$ a, but not ${ }^{*} \mathrm{kuu}>\mathrm{k}^{\mathrm{w}} \mathrm{u}$, though $k w u$ may develop from other paths). Sound change (20b) also helps explain the lack of $/ \mathrm{KP}^{\mathrm{w}} /$, since labialized consonants developed prior to labial-velars, and some changed into labial-velars. Sound change (20c) explains the presence of $/ \mathrm{gb} /$ without $/ \mathrm{kp} /$ in some languages, noted in Sec. 2.6.4. Phonetic motivation for the change of $/ \mathrm{kp}$, gb/ $>/ \mathrm{gb} / \mathrm{can}$ be found in the phonetic similarity of $/ \mathrm{kp} /$ to voiced stops noted in Section 3.1: their lack of aspiration, partial voicing, and ingressive air mechanism.

\section{Phonological models}

Zsiga [1997] suggests that categorical alternations are best represented featurally, but gradient processes are best represented gesturally. She follows this by analyzing Igbo ATR harmony with features and other vowel assimilation with a gestural account. She claims that neither representation can account for the full range of data (also see Zsiga [1995] for a similar approach). In a similar way, I will claim in this paper that there is no single phonological model which can successfully account for all the behaviors of labial-velars. While an appropriate Feature Geometry can 
account for many patterns, it fails to account for edge behavior of labial-velars. Similarly, while Articulatory Phonology can describe the edge patterns and assimilations, it cannot account for the OCP-type consonantal co-occurrence restrictions discussed earlier.

5.1 Feature Geometry. Early generative accounts of labial-velars such as Chomsky and Halle [1968] and Anderson [1976] were forced by the set of features in place at that time and their linear organization into viewing labial-velars as either labials with extreme velarization or velars with extreme labialization. Outside of this strict generative approach, Ohala \& Lorentz [1977], Ohala [1979], and Connell [1994] argue that labial-velars are neither primarily labials nor velars, but must be recognized to be a distinctly different type: labial-velars, with neither articulation primary. Here I maintain that depending on the language, either of the above approaches may be appropriate. In some languages or processes within a language both articulations act as equally prominent, but in other languages or processes, there is clearly

(21) a. Consonants

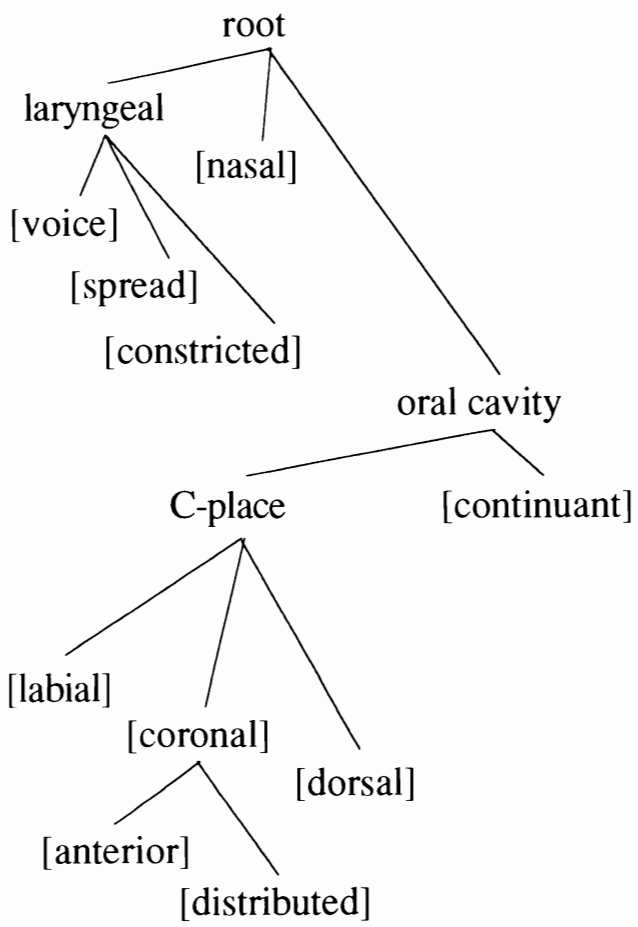

b. Vocoids

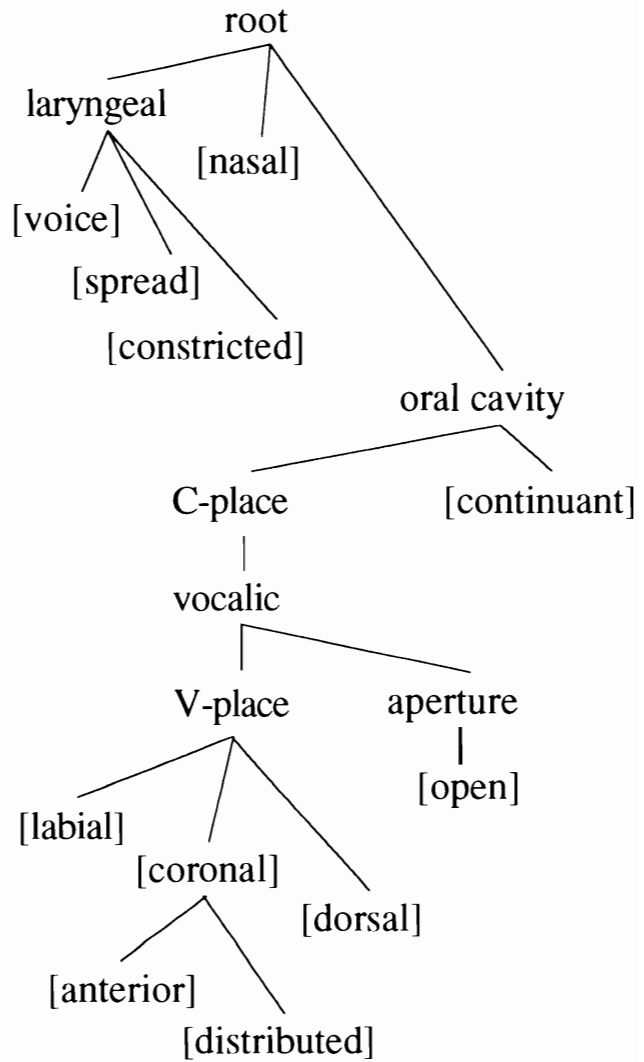


an asymmetry in phonological behavior with respect to the two articulations which argues for [labial] being primary. With the onset of non-linear approaches to phonology, both options are possible. There is still the possibility of representing labialvelars as basically velars or basically labials, but Feature Geometry opens the option of conceptualizing and representing the two articulations as equally prominent.

Sagey [1990] was the first to present a comprehensive treatment of labial-velars within the context of Feature Geometry. Since then, the model in Clements and Hume [1995] has been generally accepted as the "standard" model of Feature Geometry. Clements \& Hume-type trees for sample consonants and vowels, showing a complete set of features, are shown in (21).

This model has the advantage that segments may be treated either as units or as groupings of features. For example, the Ewe reduplication pattern which illustrated labial-velars as units must refer to the root node above; it is the entire segment which is reduplicated. Similarly, since the [nasal] feature is a daughter of the root node, a phonological spreading of [nasal] will affect the entire segment, as we have seen in Kaanse. Also, changing the [voice] feature will affect the entire segment, not just part of it. Changing a feature of the tree affects the entire segment, and this is as true for labial-velars as for any segment.

However, Feature Geometry also accommodates complex place structure, including places of articulation which may be labeled major and minor, as below, where for conciseness, the only portion of the tree displayed is the C-Place node and its daughters. The major place of articulation is given under the C-place node, and the minor place of articulation given under the V-Place node.

(22) Consonants with secondary articulation

a. $\mathrm{t}^{\mathrm{w}}$

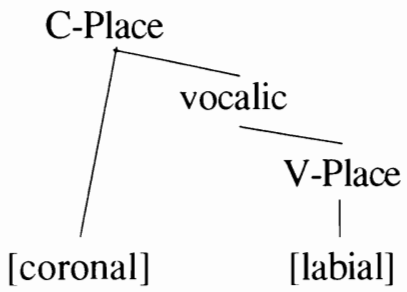

b. $p^{y}$

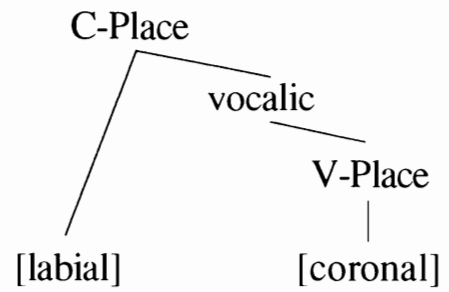

As Clements \& Hume note [1995, fn. 36], their constriction-based model makes no formal claims about the phonetic degree of stricture of the minor articulation, so the "minor" articulation could conceivably have the same degree of stricture as the major articulation. Within this model, then, three representations of labial-velars are possible and are shown below in (23). The first representation (23a) has both [labial] and [dorsal] as major articulators, and so is unambiguously [kp], but the latter two also have an alternate phonetic interpretation. The phonological behavior of a labial- 
velar in a particular language would determine which of these representations would be appropriate for that language. 8

(23) Possible labial-velar geometries

a.

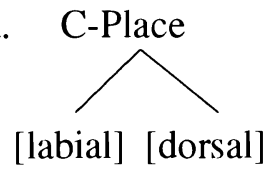

b.

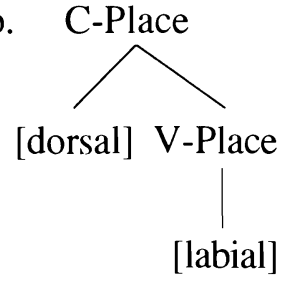

[kp]

$\left[\mathrm{kp}\right.$ or $\left.\mathrm{k}^{\mathrm{w}}\right]$

c.

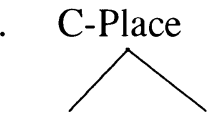

[labial] V-Place

[dorsal]

$\left[\mathrm{kp}\right.$ or $\left.\mathrm{p}^{\mathrm{r}}\right]$

We have seen in (3) that a language may have both $/ \mathrm{kp} /$ and $/ \mathrm{k}^{\mathrm{w}} /$ in its phonemic inventory. The above schema would predict that in such a language, (23b) would be the representation for $/ \mathrm{k}^{\mathrm{w}} /$ and either (a) or (c) must be the representation for $/ \mathrm{kp} /$.

In representation (23c), [labial] is the major place of articulation. This representation accounts for the grouping of labial-velars and labials as a natural class, since the primary articulation is labial for both. It correctly predicts that labial-velars and velars do not form a natural class. For example, several languages have cooccurrence restrictions of labial-velars and labials, but not labial-velars and velars. This would be looked on as an OCP-type constraint. The OCP within Feature Geometry prohibits identical adjacent elements (for a discussion of "adjacency" in this context, see Odden [1994] and Suzuki [1998]). Here, two [labial] consonants are prohibited in the same word or morpheme. However, a labial-velar freely occurs with velars, so an OCP-based conclusion is that the [dorsal] place and the [labial] place of labial-velars occur under different nodes in the geometry. Note also that the co-occurrence restriction is not a directional or edge effect: in these languages, both [...kpVp...] and [...pVkp...] are prohibited. Representation (23c) also accounts for [tp] as an allophone by spreading of the [coronal] feature from the V-Place of a vowel to the V-Place node of the KP, with concomitant delinking of the [dorsal]. ${ }^{9}$ It also could explain the neutralization of KP and P word-finally, if no secondary articulations are allowed in that environment.

Clements [1991] notes the possibility that (23b), representing $\left[\mathrm{K}^{\mathrm{w}}\right]$, is the historical predecessor of KP, and the development of this into KP consists of the [labial] being promoted to a primary place as in (23a). I would assume this could

8 While Sagey [1990] and Clements [1991] permit the possibility of two major articulations, Clements \& Hume [1995] argue against this on the basis of maximally constraining the theory. However, if no evidence is available to argue for either [dorsal] or [labial] as primary, then the choice of one of these is purely arbitrary; there is no theory-external evidence to exclude two major articulations.

9 Even in the Dagbani case, where the relevant allophones are phonetically more the palatals [cp] and $[\mathrm{jb}]$ than the alveolars, these are still considered to have [coronal] place. The palatals and alveolars are differentiated by the [anterior] feature [Clements \& Hume 1995]. 
then either remain as is or develop into (23c), with the possibility of different languages currently having different representations. Interestingly, I have not found any evidence cross-linguistically that would indicate [dorsal] as the primary place for $\mathrm{KP}$. The only phenomenon in which KP acts as [dorsal] is in nasal place assimilation, and this is strictly a left-edge effect; if the nasal is on the right of the KP, then it assimilates to the [labial], as we have seen. Thus nasal assimilation patterns are irrelevant to the issue of which articulation is primary.

It is possible that representation (23a), with [labial] and [dorsal] as both primary, may account for the rounding of $\underline{\mathrm{e}}$ in Amele before $[\mathrm{u}, \mathrm{o}, \mathrm{w}, \mathrm{gb}]$, since both places of articulation are necessary in this pattern.

Using the assumptions and above representations of Feature Geometry, one is able to account for several phonological patterns of labial-velars. However, since the [labial] and [dorsal] features are temporally unordered, Feature Geometry does not readily account for left-right asymmetries such as nasal place assimilation. A proposal for explaining the two Konni [nKP] and [jmKP] assimilations within Feature Geometry was presented in Cahill [1998] with two distinct rules. It had the disadvantage of crucially assuming [dorsal] as the primary place, and though it adequately described the patterns, it had no principled explanation for the lack of [mkp].

5.2 Articulatory Phonology. The Articulatory Phonology approach of Browman \& Goldstein [1989, 1992] incorporates a much greater degree of phonetic information, such as timing relationships, directly into the representation, than do other phonological models. The primitive units of phonology in this model are gestures which have inherent timing. In a KP, the velar gesture slightly precedes the labial ones, as

(24) a. gestural score for $\mathbf{\eta} \mathbf{K P}$

VELUM
(nasal)
TONGUE
BODY
LIPS

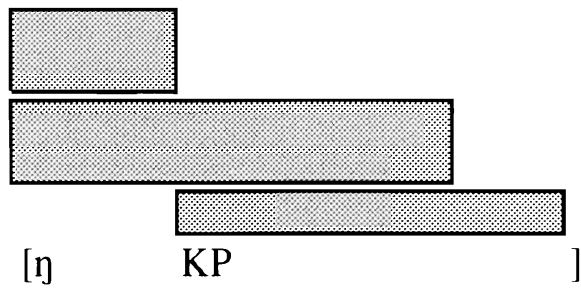

b. gestural score for $\mathbf{\eta m}-\mathbf{K P}$

VELUM
(nasal)
TONGUE
BODY
LIPS

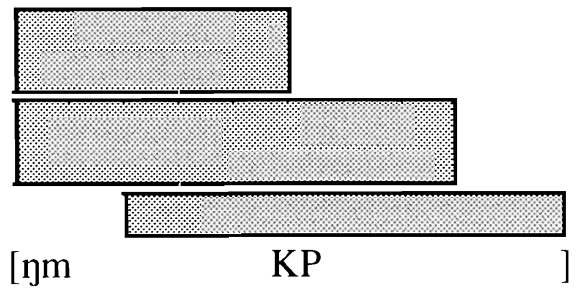


previously illustrated in (16). The "gestural score", showing the activity of the various articulators, is shown in (24) for both [nKP] and [nmKP].

Note that in (a), for [ $\eta \mathrm{KP}]$, the velum is closed before the labial gesture; nasality is finished at approximately the same time as the lips close. However, in (b), for [nmKP], the velum remains open into the labial gesture; nasality persists into the lip closure.

Articulatory Phonology can thus represent the edge effects of different nasal assimilations. However, this is purely a description of the articulator movements; it does not explain why Konni differentiates the two in the two environments of within words and across words. 10

Another phenomenon that Articulatory Phonology might help explain is the neutralization of KP to P word-finally in Amele. Given that the labial gesture is more visible, the velar gesture is less perceptible and more likely to be deleted. The occurrence of [tp] as an allophone of $/ \mathrm{kp} /$ may also be explained in gestural terms as an extension of the vocalic place gesture into the preceding consonant.

However, the gestural schema of Articulatory Phonology alone cannot account for all the phenomena of labial-velars. For example, as has been pointed out [Zsiga 1995], Articulatory Phonology predicts a possible contrast between [KP] and [PK], with the phasing relations reversed. However, not only is the contrast of these two unattested, but the $[\mathrm{PK}]$ phasing of the gestures also seems to be completely unattested. Thus we need to either enrich the theory or venture outside Articulatory Phonology for an explanation. ${ }^{11}$ Furthermore, an Articulatory Phonology account of OCP effects such as the prohibition against labial-velar and labial in the same word or morpheme would be problematic. First, since there is no way to mark one gesture as phonologically prominent, a gestural account could not single out one of two equally forceful gestures as relevant to an OCP-driven pattern. Thus there would be no reason to single out the labial gesture rather than the velar gesture, and mark the first as relevant but not the second. One might propose that the gestural timing asymmetry might be the crucial factor, but this runs into the second difficulty. There is no asymmetry in the labial-velar/labial prohibition, that is $[\ldots \mathrm{kpVp} \ldots]$ and allowing [...pVkp...] are equally disallowed. If the asymmetry of the gestures were a factor, we would expect two different co-occurrence prohibitions, depending on the left or right side of the labial-velar. That is, we would expect a prohibition against [...kVkp...] and another against $[\ldots \mathrm{kpVp} \ldots .$. . But only the latter is attested. We conclude that Articulatory Phonology cannot account for the consonantal co-occurrence restrictions involving labials and labial-velars.

\footnotetext{
10 One suggestion that has been tested in Konni is that the inherent duration of nasals is longer at boundaries such as word breaks, since the lengthening of phonetic components before a boundary is a pattern that is cross-linguistically common [Maddieson 1996]. However, measurements do not show a significant difference in nasal durations across vs. within words [Cahill 1999].

11 Three possibilities which I have considered are 1) greater perceptual salience for [KP] than $[\mathrm{PK}], 2)$ less articulatory effort for [KP] than for [PK] and 3) remnant of the historical development. Cahill [1997] is not conclusive but argues against the first possibility.
} 
5.3 Optimality Theory. Very little has been written about labial-velars within Optimality Theory (OT). Padgett [1995] is the only attempt to account for [nKP] vs. [nmKP] in OT. He uses a constraint SPREAD which forces nasals adjacent to consonants to share their place values, and a constraint *COMPSEG which penalizes the surfacing of complex segments (such as $\mathrm{kp}, \mathrm{gb}, \mathrm{nm}$ ). However, he does not account satisfactorily for the lack of [mKP], and does not deal with the challenge of major and minor articulations.

The only other work in OT dealing directly with general labial-velar phonology I am aware of is in Cahill [to appear], which deals with positional patterns of labialvelars. This work proposes a constraint MULT-son: multiply articulated segments are licensed only before sonorants. This disallows labial-velars word-finally, and most of the time syllable-finally as well, and motivates neutralization of KP word-finally.

Though organization of features has not been a major emphasis in OT work, a Feature Geometric or equivalent labeling of [labial] as primary feature and [dorsal] as secondary is still necessary in order to account for the grouping of KP with other labials to the exclusion of velars. This [labial] as primary place must be invoked to account for several patterns, including the Nupe, Amele, Efik, Nawuri, etc. groupings of KP with labials, [TP] as an allophone of /KP/, neutralization of KP with $\mathrm{P}$ word-finally (using the constraints MAX(Prim-Place) $>$ MAX(Sec-Place)), and consonant co-occurrence restrictions (using a constraint OCP[labial] and assumptions about adjacency, as in Odden [1994].

Other constraints could feasibly be proposed to account for other of the phonological patterns discussed here. For example, ${ }^{*} \mathrm{KPU}$ could be proposed to account for the restriction in some languages that a labial-velar does not co-occur with round vowels following it. However, this would be an arbitrary constraint, with no reason to admit this constraint but reject *KPA, for example. In short, OT can be used to describe the patterning of labial-velars, but adds no new insights. The frameworks previously discussed, which deal with the internal structure of labialvelars and provide the motivation behind the patterns, are outside the scope of OT.

\section{Conclusions}

While labial-velars in many languages are phonologically inert, with no alternations or co-occurrence restrictions, there are nonetheless robust cross-linguistic patterns that labial-velars follow. To adequately account for these, several approaches, not all phonological, are necessary. Historical processes, coupled with an understanding of the phonetics of labial-velars, can account for the lack of KPU, the existence of /gb/ without $/ \mathrm{kp} /$, and the lack of $/ \mathrm{KPw} /$. A Feature Geometry representation for labialvelars, with [labial] as primary, accounts for the widespread patterning of labialvelars with labials. Articulatory Phonology and phonetics can describe edge effects as well as partial vs. total nasal place assimilation, though calling this an explanatory account would be going too far. We see with Zsiga [1997] that different phenomena call for different phonological approaches. We may eventually come to the conclusion that certain of these phenomena, particularly the different patterns of nasal 
place assimilation in Konni, may be divided into phonological vs. phonetic, or lexical vs. postlexical. This is an area of ongoing research.

\section{APPENDIX: SELECTED LANGUAGES AND SOURCES}

[Note: These sources vary greatly in their depth of coverage.]

\section{PAPUAN}

Amele: Roberts 1987

Iai: Maddieson 1984

Ono: Phinnemore 1985, Wacke 1931

Yeletnye: Henderson 1975, Ladefoged \& Maddieson 1996

\section{CARIBBEAN CREOLES}

Ndyuka: Huttar 1985, Huttar \& Huttar 1972, 1994

Saramaccan: Rountree 1972

\section{AFroASIATIC, Chadic}

Gwandara: Sagey 1990

\section{NIGER-CONGO}

\section{Adamawa-Ubangi}

Gbeya: Samarin 1966

Mündü: Jeffrey \& Polley 1981

Sango: Samarin 1967, Sagey 1990

\section{Atlantic}

Kisi: Childs 1992-1994

Bantoid, Southern

Aghem: Hyman 1979

Tiv: Sagey 1990

\section{Bantu}

Digo: Kelly 1988

Sawabantu: Mutaka \& Ebobissé 1996/1997

Cross River

Efik: Cook 1969

Kana: Connell 1994
Dedua: Ladefoged \& Maddieson 1996

Nabak: McElhanon 1979

Santa Ana: Greg Mellow p.c.
Mayogo: McCord 1989

Ngbaka: Thomas 1963

Temne: Maddieson 1984

Noni: Hyman 1981

Ibibio: Connell 1994

Obolo: Connell 1994

\section{Defoid}

Igala: Silverstein 1973

Yoruba: Bamgbose 1969, Maddieson \& Ladefoged 1989, Sagey 1990

\section{Edoid}


Gur

Birifor: Kuch 1993

Dagaari: Kennedy 1966

Deg: Crouch in press

Frafra: Schaefer 1975

Kaanse: Showalter 1997

Konni: Cahill 1992, 1998, to appear

Nafaara: Jordan 1980

Sisaala-Pasaale: Toupin 1995

Supyire: Carlson 1994

Tyebaara Senufo: Mills 1984
Buli: Kröger 1992

Dagbani: Wilson \& Bendor-Samuel 1969

Dilo: Jones 1987

Hanga: Hunt 1981

Konkomba: Steele \& Weed 1966

Kusaal: Spratt \& Spratt 1968

Phwin: Kevin Warfel p.c.

Sucite: Garber 1987

Tampulma: Bergman, Gray \& Gray 1969

Vagla: Crouch and Smiles 1966

\section{Igboid}

Igho: Connell 1994, Ladefoged, Williamson, Elugbe, \& Uwalaka 1976

\section{Ijoid}

Ijo: Williamson 1969

\section{Kru}

Krahn: Marchese 1989

\section{Kwa}

Akan: Dolphyne \& Dakubu 1988

Baule: Dolphyne \& Dakubu 1988

Ewe: Ansre 1963, Ladefoged \& Maddieson 1996

Gã: Ryder 1987

Gonja: Painter 1970

Nawuri: Casali 1995

Nkonya: Lear \& Peacock ms

\section{Mande}

Bambara, southern: Welmers 1973

Kpelle: Welmers 1962, 1973

Maninka: Welmers 1973

\section{Nupoid}

Gwari: Rosendall 1992,

Hyman \& Magaji 1970

\section{Platoid}

Eggon: Ladefoged \& Maddieson 1996

\section{NILO-SAHARAN}

Central Sudanic

Avokaya: Callinan 1981

Bongo: Kilpatrick 1985

Lulubo: Andersen 1987

Mödö: Persson 1981
Tepo: Marchese 1989

Anyi: Dolphyne \& Dakubu 1988

Chakosi/Anufo: Stanford \& Stanford 1970, Dolphyne \& Dakubu 1988, Adjekum, Holman \& Holman 1993

Gıdıre (Adele): Kleiner 1989

Guang languages: Snider 1990

Nchimburu: Price 1975

Nzema: Westermann \& Bryan 1952, Chinebuah 1963, Dolphyne \& Dakubu 1988

Dan: Bearth \& Zemp 1967

Loma/Lorma: Long 1971

Nupe: Banfield 1914, Smith 1967

Mada: Price 1989

Baka: Parker 1985

Lendu: Demolin 1995, Dimmendaal 1986

Madi: Andersen 1986

Ngiti: Kutsch Lojenga 1994 


\section{REFERENCES}

Andersen, Torben. 1986. "The phonemic system of Madi." Afrika und Übersee 69, 2:193-208.

Andersen, Torben. 1987. "An Outline of Lulubo Phonology." Studies in African Linguistics 18,1:39-66.

Anderson, Stephen R. 1976. "On the description of multiply-articulated consonants." Journal of Phonetics 4: 17-27.

Ansre, Gilbert. 1963. "Reduplication in Ewe." Journal of African Languages 2: 128-132.

Bamgbose, Ayo. 1969. "Yoruba." In E. Dunstan (ed.), Twelve Nigerian Languages. New York: African Publishing Corp. Pp. 163-172.

Banfield, A. W. 1914. Dictionary of the Nupe Language, Vol 1: Nupe-English. Shonga, Nigeria: The Niger Press. Republished 1969 by Gregg International Publishers, Ltd., England.

Bearth, T. and H. Zemp. 1967. "The phonology of Dan (Santa)." Journal of African Languages 6:9-29.

Bendor-Samuel, John (ed.). 1989. The Niger-Congo Languages. Lanham, MD: University Press of America/SIL.

Bergman, Richard, Ian and Claire Gray. 1969. "The Phonology of Tampulma." Collected Field Notes Series No. 9. The Institute of African Studies, University of Ghana, Legon.

Browman, C.P. and L. Goldstein. 1989. "Articulatory gestures as phonological units." Phonology 6:201-251.

Browman, C. P. and L. Goldstein. 1992. "Articulatory phonology: an overview." Phonetica 49:155-180.

Cahill, Michael. 1992. "A preliminary phonology of the Konni language." Collected Field Notes Series No. 20. IAS, University of Ghana, Legon.

Cahill, Michael. 1997. "Perception of Consonant Clusters and Variable Gap Time." Ohio State University Working Papers in Linguistics 50: Papers from the Linguistics Laboratory, pp. 1-10. 
Cahill, Michael. 1998. "Nasal assimilation and labiovelar geometry." In Ian Maddieson \& Thomas J. Hinnebusch (eds.), Language History and Linguistic Description in Africa. Trends in African Linguistics 2. (Papers presented at 26th ACAL, UCLA, 1995). Trenton, NJ: Africa World Press. Pp 127-136.

Cahill, Michael. 1999. "Aspects of the Morphology and Phonology of Kçnni." Ph.D. dissertation, Ohio State University.

Cahill, Michael. To appear. "Positional contrast and labial-velars." Ohio State University Working Papers in Linguistics.

Callinan, Lynne. 1981. "A preliminary study of Avokaya phonemes." Occasional Papers in the Study of Sudanese Languages 1:64-73. Juba: Summer Institute of Linguistics, Institute of Regional Languages, and the University of Juba.

Carlson, Robert. 1994. A Grammar of Supyire. New York: Mouton de Gruyter.

Casali, Roderic F. 1995. "Labial opacity and roundness harmony in Nawuri." Natural Language and Linguistic Theory 13:649-663.

Childs, G. Tucker. 1992-1994. "Language typology and reconstruction: the prenasalized stops of Kisi." Studies in African Linguistics 23: 65-80.

Chinebuah, Isaac K. 1963. "The category of number in Nzema." Journal of African Languages 2:244-59.

Chomsky, Noam and Morris Halle. 1968. The Sound Pattern of English. New York: Harper \& Row.

Clements, George N. 1991. "Place of articulation in consonants and vowels: A unified theory." Working Papers of the Cornell Phonetics Laboratory No. 5, $77-123$.

Clements, G.N. and Elizabeth V. Hume. 1995. "The Internal Organization of Speech Sounds." In John Goldsmith (ed.), A Handbook of Phonological Theory. Oxford: Blackwell. Pp. 245-306.

Cohen, Kevin. 1997. "Aspects of the grammar of Kukú." Ms, Ohio State University.

Connell, Bruce. 1991. "Accounting for the reflexes of labial-velar stops.” In M. Rossi (ed.), Proceedings of the XIIth ICPhS, Aix-en-Provence, Vol. 3:110-113.

Connell, Bruce. 1994. "The structure of labial-velar stops." Journal of Phonetics 22:441-476. 
Connell. Bruce. 1995. "The historical development of Lower Cross consonants." Journal of African Languages and Linguistics 16:41-70.

Cook, Thomas. 1969. "Efik." In E. Dunstan (ed.), Twelve Nigerian Languages. New York: Africana Publishing Corporation. Pp. 35-46.

Crouch, Marjorie. In press. "A phonology of Deg." Collected Field Notes Series The Institute of African Studies, University of Ghana.

Crouch, Marjorie and Nancy Smiles. 1966. The Phonology of Vagla. Collected Field Notes Series No. 4. The Institute of African Studies, University of Ghana, Legon.

Demolin, Didier. 1995. "The phonetics and phonology of glottalized consonants in Lendu." In Bruce Connell \& Amalia Arvanti (eds.), Phonology and Phonetic Evidence. Papers in Laboratory Phonology IV. Cambridge: Cambridge University Press. Pp. 368-385.

Dimmendaal, Gerritt J. 1986. "Language Typology, Comparative Linguistics, and Injective Consonants in Lendu." Afrika und Übersee 69.2:161-192

Dolphyne, F. A. and M. E. Kropp Dakubu. 1988. "The Volta-Comoé Languages." In M. E. Kropp Dakubu (ed.), The Languages of Ghana. London: Kegan Paul International. Pp. 50-90.

Dunstan, Elizabeth. 1969. Twelve Nigerian Languages. New York: Africana Publishing Corporation.

Elugbe, Ben O. 1986. Comparative Edoid: Phonology and Lexicon. Delta Series No. 6. University of Port Harcourt Press.

Folarin, Antonia Yetunde. 1987. "Lexical phonology of Yoruba nouns and verbs." Ph.D. dissertation, University of Kansas.

Garber, Ann E. 1987. “A Tonal Analysis of Senufo: Sucite Dialect.” Ph.D. dissertation, University of Illinois at Urbana-Champaign.

Grimes, Joseph E. (ed.). 1972. Languages of the Guianas. Norman: SIL/University of Oklahoma.

Henderson, James E. 1975. Yeletnye, the Language of Rossel Island. in Studies_in Languages of Central and Southeast Papua, T.E. Dutton (ed.). Pacific Linguistics C-29.817-34.

Herault, Georges. 1969. Étude phonétique et phonologique de l'adioukrou. Abidjan: Insititut de Linguistique Appliquée. 
Herault, Georges. 1982. "L'Adioukrou.” In G. Herault (ed.), Atlas des langues Kwa de Côte d'Ivoire, vol. I. Abidjan: Université d'Abidjan, Insititut de Linguistique Appliquée. Pp. 129-153.

Hunt, Geoffrey R. 1981. "A Phonology of the Hanga Language.” Collected Field Notes Series No. 18. The Institute of African Studies, University of Ghana, Legon.

Huttar, George L. 1985. "Sources of Ndjuka African vocabulary." Nieuwe WestIndische Gids (New West Indian Guide) 59.1:45-71.

Huttar, George L. and Mary L. Huttar. 1972. "Notes on Djuka Phonology.” In J. Grimes (ed.), Languages of the Guianas. Norman: SIL/University of Oklahoma. Pp. 1-11.

Huttar, George L. and Mary L. Huttar. 1994. Ndyuka. London: Routledge.

Hyman, Larry M. 1979. "Phonology and noun structure." In Larry M. Hyman (ed.), Aghem Grammatical Structure. Southern California Occasional Papers in Linguistics No. 7. USC. Pp. 1-72

Hyman, Larry M. 1981. Noni Grammatical Structure. Southern California Occasional Papers in Linguistics No. 9. USC.

Hyman, Larry M. and Daniel J. Magaji. 1970. Essentials of Gwari Grammar. Occasional Publication No. 27, Institute of African Studies, University of Ibadan.

Jeffrey, Dorothea and Linda Polley. 1981. "Phonology and Morphophonemics in Mündü." Occasional Papers in the Study of Sudanese Languages 1:1-42. Juba: Summer Institute of Linguistics, Institute of Regional Languages, and the University of Juba.

Jordan, Dean. 1980. "The phonology of Nafaara." Collected Field Notes Series No. 17. The Institute of African Studies, University of Ghana, Legon.

Jones, Peggy. 1987. “The phonology of Dilo." Collected Field Notes Series No. 18. The Institute of African Studies, University of Ghana, Legon.

Kelly, John. 1974. "Phonology and African linguistics." African Language Studies 15:97-109.

Kelly, John. 1988. “The velar labials in ChiDigo.” In David Bradley, Eugénie J.A. Henderson, and Martine Mazaudon (eds.), Prosodic analysis and Asian linguistics: to honour R.K Sprigg. Pacific Linguistics, C-104: 43-50. 
Kennedy, Jack. 1966. "The phonology of Dagaari." Collected Field Notes Series No. 6. The Institute of African Studies, University of Ghana, Legon.

Kilpatrick, Eileen. 1985. "Bongo phonology." Occasional Papers in the Study of Sudanese Languages 4: 1-62. Juba: Summer Institute of Linguistics, Institute of Regional Languages, and the University of Juba.

Kleiner, Renate. 1989. "Phonology Notes of Gıdıre, the language of the Adele." Ms., GILLBT, Tamale, Ghana.

Kröger, Franz. 1992. Buli-English Dictionary. Münster: Lit Verlag.

Kuch, Lawrence. 1993. "The phonology of Birifor." Collected Field Notes Series No. 21. The Institute of African Studies, University of Ghana, Legon.

Kutsch Lojenga, Constance. 1994. "Ngiti: A Central-Sudanic Language of Zaire." Nilo-Saharan Linguistic Analyses and Documentation Vol. 9. Köln: Köppe.

Ladefoged, Peter. 1968. A Phonetic Study of West African Languages. (2nd ed.) Cambridge University Press.

Ladefoged, Peter and Ian Maddieson. 1996. The Sounds of the World's Languages. Cambridge, MA: Blackwell Publishers.

Ladefoged, Peter, K. Williamson, B. Elugbe, and S. A. Uwalaka. 1976. "The stops of Owerri Igbo." Studies in African Linguistics, supplement 6:147-162.

Lear, J. and W. Peacock. n.d. "An Introduction to Nkonya Phonology.” Ms. Ghana Institute of Linguistics, Literacy, and Bible Translation, Tamale, Ghana.

Liêm, Nguyên-Dang. 1970. Vietnamese Pronunciation. Honolulu: University of Hawaii Press.

Long, Ronald. 1971. "A comparative study of the Northern Mande languages." Ph.D. dissertation, Indiana University.

Maddieson, Ian. 1984. Patterns of Sounds. Cambridge: Cambridge University Press.

Maddieson, Ian. 1990. "Shona velarization: complex consonants or complex onsets?" UCLA Working Papers in Phonetics 74: 16-34.

Maddieson, Ian, and Peter Ladefoged. 1989. "Multiply articulated segments and the feature hierarchy." UCLA Working Papers in Phonetics 72:116-138. 
Mafeni, Bernard, 1969. "Isoko.” In E. Dunstan (ed.), Twelve Nigerian Languages. New York: Africana Publishing Corporation. Pp. 115-124.

Marchese, Lynn. 1989. "Kru." In John Bendor-Samuel (ed.), The Niger-Congo Languages. Lanham, MD: University Press of America/SIL. Pp. 119-140.

McCord, Michael S. 1989. "Acoustical and autosegmental analyis of the Mayogo vowel system.” M. A. thesis, University of Texas at Arlington.

McElhanon, K.A. 1979. “A fresh look at Nabak morphophonemics.” Kivung 12,1: $74-88$.

Mills, Elizabeth. 1984. Senoufo Phonology, Discourse to Syllable. Dallas: Summer Institute of Linguistics.

Mutaka, Ngessimo M. and Carl Ebobissé. 1996/97 "The Formation of Labial-velars in Sawabantu: Evidence for Feature Geometry." Journal of West African Linguistics XXVI,1: 3-14.

Odden, David. 1994. Adjacency parameters in phonology. Language 70.2:289-330.

Ohala, John. 1979. "Universals of labial velars and De Saussures' chess analogy." Proceedings of Ninth International Congress of Phonetic Sciences, Vol II. Copenhagen, pp. 41-47.

Ohala, John J. 1997. The Relation between Phonetics and Phonology. In William J. Hardcastle and John Laver (eds.), The Handbook of Phonetic Sciences. Cambridge, MA: Blackwell. Pp.674-694.

Ohala, John, and James Lorentz. 1977. "The story of [w]: An exercise in the phonetic explanation for sound patterns." Berkeley Linguistic Society 3:577-599.

Ohala, John J. and Manjari Ohala. 1993. "The phonetics of nasal phonology: theorems and data." In Marie K. Huffman \& Rena A. Krakow (eds.), Nasals, Nasalization, and the Velum. San Diego, CA: Academic Press. Pp. 225-249.

Padgett, Jaye. 1995. "Partial class behavior and nasal place assimiliation." Proceedings of the Southwestern Optimality Theory Workshop, Coyote Working Papers in Linguistics, pp. 145-183. Tucson: University of Arizona.

Painter, Colin. 1970. Gonja: A phonological and grammatical study. Bloomington: Indiana University.

Parker, Kirk. 1985. "Baka Phonology." Occasional Papers in the Study of Sudanese Languages 4:63-85. Juba: Summer Institute of Linguistics, Institute of Regional Languages, and the University of Juba. 
Janet Persson. 1981. "Notes on the Phonology of Jur Mödö." Occasional Papers in the Study of Sudanese Languages 1:43-54. Juba: Summer Institute of Linguistics, Institute of Regional Languages, and the University of Juba.

Phinnemore, Thomas R. 1985. "Ono Phonology and Morphophonemics." Papers in New Guinea Linguistics No. 22, 173-214. Pacific Linguistics Series A 63.

Ponelis, F. 1974. "On the dynamics of velarization and labialization: Some Bantu evidence." Studies in African Linguistics 5:27-58.

Price, Norman. 1975. "The phonology of Nchimburu." Collected Field Notes Series No. 14. The Institute of African Studies, University of Ghana, Legon.

Price, Norman. 1989. "Notes on Mada phonology." Language Data, Africa Series, Publication 23. Dallas: Summer Institute of Linguistics.

Roberts, John R. 1987. Amele. New York: Croon Helm.

Rosendall, Heidi James. 1992. A Phonological Study of the Gwari Lects. Dallas: Summer Institute of Linguistics.

Rountree, S. Catharine. 1972. "The Phonological Structure of Stems in Saramaccan." In Joseph Grimes (ed.), Languages of the Guianas. Norman: SIL/ University of Oklahoma. Pp. 22-27.

Ryder, Mary Ellen. 1987. "An autosegmental treatment of nasal assimilation to labial-velars." Proceedings of the Chicago Linguistic Society 23, vol. 2 (Parasession on Autosegmental and Metrical Phonology). Pp. 253-265.

Sagey, Elizabeth. 1990. The Representation of Features in Non-linear Phonology. Garland Press.

Samarin, W.J. 1966. The Gbeya Language. University of California Press, Berkeley and Los Angeles.

Samarin, W.J. 1967. A Grammar of Sango. Mouton: The Hague.

Schaefer, Robert. 1975. "The phonology of Frafra." Collected Field Notes Series No. 15. The Institute of African Studies, University of Ghana, Legon.

Selkirk, Elisabeth. 1993. "[Labial] relations.” Ms., University of Massachusetts, Amherst.

Showalter, Stuart. 1997. "Coup de glotte, nasalité, et schèmes syllabiques en kaanse." Gur Papers/Cahiers Voltaïques No 2: 137-146. 
Silverstein, Raymond O. 1973. "Igala historical phonology." Ph.D. dissertation, UCLA.

Smith, N. V. 1967. "The phonology of Nupe." Journal of African Languages 6.2: 153-169

Snider, Keith 1990. "Studies in Guang phonology." Doctoral dissertation, University of Leiden.

Spratt, David and Nancy. 1968. "The phonology of Kusaal." Collected Field Notes Series No. 10. The Institute of African Studies, University of Ghana, Legon.

Stanford, Ronald and Lyn. 1970. "The phonology and grammar of Chakosi." Collected Field Notes Series No. 11. The Institute of African Studies, University of Ghana, Legon.

Steele, Mary, and Gretchen Weed. 1966. "The phonology of Konkomba." Collected Field Notes Series No. 3. The Institute of African Studies, University of Ghana, Legon.

Suzuki, Keiichiro. 1998. "A typological investigation of dissimilation.” $\mathrm{Ph} . \mathrm{D}$. dissertation, University of Arizona (available on Rutgers Optimality Archive, ROA-281-0998).

Thomas, Jacqueline M. C. 1963. Le Parler Ngbaka de Bokanga. Paris: Mouton \& Co.

Toupin, Mike. 1995. "The phonology of Sisaale-Pasaale." Collected Field Notes Series No. 22. The Institute of African Studies, University of Ghana, Legon.

Wacke, K. 1931. "Formenlehre der Ono-Sprache (Neuguinea)." Zeitschrift für Eingeborenen-Sprachen 21:161-208.

Welmers, Wm. E. 1962. “The phonology of Kpelle.” Journal of African Languages 1:69-93.

Welmers, Wm. E. 1973. African Language Structures. Berkeley and Los Angeles, California: University of California Press.

Westermann, D., and M. A. Bryan. 1952. The languages of West Africa. Handbook of African Languages, Part 2. London: Oxford University Press for the International African Institute.

Williamson, Kay. 1969. “Ijo.” In E. Dunstan (ed.), Twelve Nigerian Languages. New York: Africana Publishing Corporation. Pp. 97-114. 
Wilson, W. A. A. and John Bendor-Samuel. 1969. "The phonology of the nominal in Dagbani." Linguistics 52:56-82.

Zsiga, Elizabeth. 1995. "An acoustic and electropalatographic study of lexical and postlexical palatalization in American English.” In Bruce Connell \& Amalia Arvanti (eds.), Phonology and Phonetic Evidence. Papers in Laboratory Phonology IV. Cambridge: Cambridge University Press. Pp. 282-302.

Zsiga, Elizabeth. 1997. "Features, gestures, and Igbo vowel assimilation." Language 73: 227-274.

SIL

7500 W. Camp Wisdom Road

Dallas, TX 75236

Mike_Cahill@sil.org
[Received November 1998; revision received May 1999; accepted June 1999] 